\title{
Sport in Spanish prisons: Towards the Third Degree or the Third Half?
}

\author{
Deporte en las prisiones españolas: ¿hacia el tercer grado o el tercer tiempo? \\ Joaquina Castillo-Algarra ${ }^{1}$, Bruno García-Tardón ${ }^{2}$, Rodrigo Pardo ${ }^{3}$ \\ 1 Facultad de Educación, Psicología y Ciencias del Deporte. Universidad de Huelva. España. \\ 2 Facultad de Educación y Salud. Universidad Camilo José Cela. España. \\ 3 Facultad de Ciencias de la Actividad Física y del Deporte-INEF. Universidad Politécnica de Madrid. España.
}

CORRESPONDENCIA:

Joaquina Castillo Algarra

joaquinacastillo@gmail.com

\begin{abstract}
Published research on the effects of sport among the prison population in Spain has come to conflicting conclusions, creating a confusing picture: is it rehabilitation, mere fun, or a form of social control? What lies behind this disparity of findings? Can a prison sports programme have positive effects on inmates, contributing to their reintegration into society? If so, what specific features should the programme have in order to achieve this outcome? To shed some light on the area, answering these questions, is the objective of this article. Firstly, we carried out a review of the Spanish and international literature on the subject, which led us to conclude that a sports programme could in fact have positive effects on inmates' reintegration, provided that it complied with a certain set of requisites. However, the studies we reviewed made no mention of these requirements, despite their importance. Thus, the second step in our research was to select a sports programme in a Spanish prison which complied with the requisites and to investigate its effects on the inmates taking part. Through participant observation and interviews we found that the programme did indeed have positive effects among prisoners. This represents an important advance in our knowledge, since we were then able to set out the guidelines which the design and implementation of prison sports programmes should follow if they are to aid the social reintegration of inmates. This is the foremost contribution and value of the present study.
\end{abstract}

Key words: sport, physical activity, prisons, inmates, Spain.

\section{Resumen}

Las investigaciones publicadas sobre los efectos del deporte entre la población reclusa en España muestran conclusiones contradictorias, creando una situación confusa: ¿es rehabilitación, simple diversión, o una forma de control social? ¿Qué se esconde detrás de esta disparidad de resultados? ¿Puede un programa de deportes de la cárcel tener efectos positivos sobre los internos, contribuyendo a su reinserción en la sociedad? Si es así, ¿qué características específicas debería tener un programa que busca alcanzar este objetivo? Para arrojar algo de luz sobre este tema, el objetivo de este artículo es responder a estas preguntas. En primer lugar, se llevó a cabo una revisión de la literatura española e internacional sobre este tema, lo que llevó a la conclusión de que un programa de deportes podría, de hecho, tener efectos positivos sobre la reinserción de los internos, siempre que se cumpla con un conjunto claro de requisitos. Sin embargo, en los estudios revisados no se hace mención de estos requisitos, a pesar de su importancia. De esta forma, el segundo paso en nuestro estudio fue seleccionar un programa de deportes en una cárcel española que cumple con estos requisitos e investigar sus efectos sobre los internos que participaron. A través de la observación participante y las entrevistas encontramos que el programa tuvo efectos positivos entre los presos. Esto representa un avance significativo en nuestro conocimiento, ya que permite establecer las directrices y el diseño para implementar programas deportivos en centros penitenciarios con el fin de ayudar a la reinserción social de los internos. Esta es la principal contribución y el valor del presente estudio.

Palabras clave: deporte, actividad física, centros penitenciarios, reclusos, España. 


\section{Introduction}

Sport is currently seen as one among a range of treatment activities for the prison population. Despite this, studies of sports in prisons reach contradictory conclusions. In Spain, these can be classified under three headings:

- Studies which find no positive effects on the rehabilitation and social reintegration of the inmate population (Arribas, Mantecón, Rodríguez \& Sánchez, 2001; Negro, 1995 and Ríos, 1986 \& 2004) but concludes that the sport could offer another benefits like contributes to "health prevention and development in all areas" or promotes "the setting of organizational guidelines for daily life (order, punctuality, routines, etc.), vitally necessary to a mostly destructured population" (Ríos, 2004, p. 81).

- A second group of studies finds benefits in the physical fitness of internees and in the struggle against drug addiction (Pérez-Moreno et al., 2007), as well as in the educational potential of sports and their effective aid in modifying behaviour and values, essential for prisoners' reintegration into society (Castillo, 2005 \& 2007; Chamarro, 1997; Chamarro, Blasco \& Palenzuelo, 1998; Moscoso, Pérez, Muñoz, González \& Rodríguez-Morcillo, 2012);

- Lastly, a third group finds that sports in prison do not only result in benefits for those inmates taking part, but also that for the prison management they constitute a means of social control used to maintain order and/or repression (Fornons, 2008; Martos, Devís \& Sparkes, 2009). In this group we come across some surprisingly negative claims, for example: "(sport) is a type of institutional control and surveillance, similar to the past, when bromide was administered" (Fornons, 2008, p. 221). "Physical and sports activities become small areas of freedom which are used as negotiating counters...to keep inmates busy and under control" (Martos, Devís \& Sparkes, 2009, p. 409).

In studies on the effects of prison sports programmes published outside of Spain we find a certain agreement on their benefits and advantages. These are:

1. Sport is one of the most motivating activities for inmates, independently of their age, education (Lobo, 1975), ethnic background, type of offence or length of sentence (Cudd, 1978).

2. The physical benefits are general health gains, weight loss, etc. (Hagan, 1990) and improvements in habits, such as diet and reducing or giving up smoking (Garnier, Minotti \& Labridy, 1996). Doing sport also helps build a healthy body in an unhealthy environment (Sabo, 2001), enhancing general physical fitness and mental health (Ionescu, Parisot \& Irode 2010).

3. The psychological benefits are that sport lowers stress and anxiety (Buckaloo, Krug \& Nelson, 2009; Hagan, 1990; Lechich, 1984); increases selfconfidence and self-control and decreases frustration (Clark, Haag \& Owen, 1986); improves mental health and counters feelings of despair (Cashin, Potter, \& Butler, 2008); and is of enormous use in helping inmates sleep (Elger, 2009; Harner \& Budescu, 2014). Further, it makes prisoners feel happy (Reeves, 1973): they forget that they are convicts, feeling like "normal" people while they are doing sport (Long, 1983). It also creates areas of freedom for physical expression (in an environment dedicated to depriving inmates of their liberty), with all the psychological benefits that this implies (Gras, 2005).

4. Sport is an essential aid in giving up drugs (Long, 1983) and in avoiding falling back into the habit (Chevry, Aoun \& Clement, 1992; Nelson, Specian, Tracy \& DeMello, 2006; Stöver \& Thane, 2011).

5 . It counters the prison subculture by fomenting leisure activities and conversations which have no relation to prisoners' criminal activities (Clarke, Haag y Owen, 1986).

6. Inmates learn to follow rules and regulations, and this contributes to their rehabilitation (Bodin, Robene, Heas \& Sempre, 2007; González \& Smith, 1974; O’Morrow \& Reynolds, 1989). “All their lives prisoners have lived by breaking rules, with selfdestructive tendencies, taking the wrong path in life; on the playing field they cannot do this, and it is a great lesson for them" (Middleton, 1983, pp. 14-15). This acquisition of habits and rules can be applied outside the jail (Viñas, 2012), and thus it is considered that sport contributes to inmates' social reintegration (Ionescu, Parisot \& Irode 2010; Leberman, 2007).

7. Also, these activities can enable some internees to build a profession as monitors, referees, etc., in a range of different sports (Dewey, 1976).

On the other hand, some studies affirm that some institutions use sports programmes to exert their power, taking prisoners' minds off their situation and maintaining order and correct behaviour (Aguilar \& Asmussen, 1990; Crutchfiel, Garrette \& Worrall, 1981), findings similar to the third group of Spanish studies cited above.

However, as Bredemeier (1995a, 1995b) remarks, physical activity and sport do not create social and personal values by themselves. They are an excellent 
means of fostering and developing such values, but this depends on the use, correct or otherwise, made of them. Thus, all sports programmes should fulfil a series of requirements if they are to promote social and personal values among the individuals taking part (Dominguez, Jiménez \& Durán, 2012; Doty, 2006; Escartí, Pascual \& Gutiérrez, 2005; Gutiérrez, 1995; Wandzilak, 1985). To achieve this a sports programme should:

1. Be adapted to the characteristics and needs of the target group;

2. Have continuity in time;

3. Feature monitors with enough training to effectively promote values through the practice of sports, and with a firm intention to achieve this;

4. Take place in a context favourable to the sports programme being carried out appropriately.

These requirements are equally valid for prison sports programmes (Gallant, Shery \& Nicholson, 2014), along with a series of other factors which can contribute to their success in this specific context. Despite the importance of these requisites, as far as we are aware no published studies make reference to their fulfilment in the sports programmes they analyse. This is not to say that the requirements are not fulfilled, but that we have no evidence of this. What we do know is that not all sports programmes carried out in Spanish prisons include a professional sports specialist (Devís, Martos \& Sparkes, 2010); and in some prisons which do employ such a specialist, we do not know what objectives the programme seeks to achieve. To counter this lack, a fundamental objective of this study is to analyse one prison sports programme which fulfils the requirements cited above, in order to determine what effects it has on the inmates taking part. Therefore, we investigated whether these effects were positive for the inmates' health and if they contributed to their rehabilitation and reintegration into society, or whether their main effects were in maintaining social control and order for the penitentiary institution and/or merely as a means of distraction for the inmates and/or the prison. Further, by determining whether we could guarantee the positive effects of a prison sports programme when this complied with a series of requisites, we were able to establish, on the basis of these requisites, the guidelines that the design and implementation a prison sports programme should follow in order to contribute to the social reinsertion of the inmates taking part. This represents an advance in our knowledge in the area and is the principal contribution and value of the study.

\section{Method}

The study was carried out in a Spanish prison. Each module had a small gym and a courtyard with basketball nets, five-a-side football goals and a table tennis table. In the central sector of the prison was the zone known as the socio-cultural area, which included a football pitch, a sports centre, changing rooms, a gym, a volleyball court, a frontenis (wall tennis) court and an area for boxing. The human resources for the sports area of the prison consisted of: one sports monitor, known as Middle-Qualified Specific Activities Monitor (Titulado Medio de Actividades Específicas-TMAE), holding a university sports degree (middle or higher); and a sports coordinator with the professional category of an educator and no required university qualification, despite being on a higher salary scale than the TMAE (any prison staff member might become a coordinator through internal promotion).

The activity chosen for this study was the football school, promoted by a Real Madrid Foundation (Foundation) and regulated through an annuallyrenewed agreement between the General Penitentiary Board and the Foundation. The sports programme had the following features:

- The trainer responsible for the activity had sufficient training to effectively transmit values through sports, holding a degree in Sports and Physical Activities Sciences and with the qualification of Higher Sports Technician (football);

- The trainer also had the basic aim of educating the inmates taking part, as we were able to verify not only through his own testimony but also through the participant observation, we carried out in each of the sessions;

- The trainer was also an 'ordinary person,' i.e. not a member of the prison staff;

- The programme had an extended time-scale.

- Lastly (and an essential point) the inmates had freely and voluntarily given their consent to take part in the school and to abide by its rules and regulations.

The programme also complied with the rest of the requisites cited previously: it involved a team sport (football), it was done in the open air and it included some matches against teams from outside the prison.

The training sessions took place every Friday morning from 9:30 to 12:45. At three points in each session the trainer talked to the participants: at the beginning, to discuss organizational issues, in the middle and at the end, these last devoted to 
Table 1. Phases of fieldwork and number of interviews.

\begin{tabular}{lll}
\hline Phases & Weeks & Fieldwork \\
\hline Initial phase & $\begin{array}{l}\text { Oct-Nov } \\
\left(1^{\text {st }}-3^{\text {rd }} \text { session }\right)\end{array}$ & $\begin{array}{l}\text { Trainer interviews (3) } \\
\text { Participant observation }\end{array}$ \\
\hline $\begin{array}{l}\text { Intermediate } \\
\text { phase }\end{array}$ & $\begin{array}{l}\text { Nov-Dec } \\
\left(4^{\text {th }}-12^{\text {th }} \text { session }\right)\end{array}$ & $\begin{array}{l}\text { Trainer interviews (9) } \\
\text { Participant observation }\end{array}$ \\
\hline & $\begin{array}{l}\text { Jan-Feb } \\
\left(13^{\text {th }} \text { session }\right)\end{array}$ & $\begin{array}{l}\text { Trainer interviews (1) } \\
\text { Prison staff interviews (6) } \\
\text { Interviews with inmates taking part (9) } \\
\text { Interview with inmate responsible for maintenance (1) } \\
\text { Interview with responsible from General Penitentiary Board (1) }\end{array}$ \\
\hline
\end{tabular}

compliance with rules and the attitudes and behaviour of the group and/or particular inmates.

To study the impact of the programme we chose a qualitative methodology, based on two techniques: the in-depth interview and participant observation. The participants in the study were: the trainer (a member of the Foundation) in charge of the activity, nine of the 30 inmates enrolled in the football school, and the prisoner responsible for the upkeep of the sports centre, who assisted the trainer at each session. We also interviewed prison staff with direct and indirect responsibility for the sports programme: the centre director, the subdirector for treatment, the medical subdirector, the sports coordinator, two educators from the modules where the participating inmates were housed, the TMAE and a person responsible from General Penitentiary Board.

The script for the staff interviews ranged from general questions on the workings and organization of the prison to specific questions about the effects of the football school (transmission of values, participants' views of its use as a tool for social intervention and the rehabilitation of inmates, etc.). In the prisoner interviews we investigated the same factors as well as questioning them on the benefits they had obtained from participating in the programme.

The researcher carrying out participant observation stayed on one side of the football pitch in order to observe "the phenomenon in its normal functioning" (Callejo, 2002, p. 410), interacting with the inmates and the trainer before the session, during the break and at the end of the session, when the trainer was asked for his opinions on any incidents that had occurred. All of this (attitudes, opinions and circumstances) was recorded in the observation sheets. The organization of fieldwork is showed in the table 1.

All the interviewees gave their consent to take part in the study. All the interviews were recorded and transcribed. To protect their anonymity the inmates' names were substituted with another ones, while on the interview transcripts the prison staff and other professionals are referred to only by their position; the educators are referred to as Educator 1 and 2 and the Middle-Qualified Specific Activities Monitor as TMAE.

Two permits were needed to carry out the study: one from the General Penitentiary Board and another from the Foundation. The prison provided us with identity/accreditation cards for access to the prison for the duration of the study.

The data obtained from the interviews and observation sheets were transcribed and subsequently analysed using the programme QSR X-Sight 2.0.

\section{Consequences of a sports program in prison: Between utopia and reality}

The sports programme: Something more than just learning to play football?

According to the staff working with the inmates, the football programme's main impact was in transmitting values: "I see it as really positive. Because we're putting across a system of values... And through sport we can show the way..." (educator 1 ). "It teaches respect for rules and transmits values more easily than other activities" (educator 2). "You see the benefits on a personal level, since it's an activity whose aim is to convey positive values and ease their reintegration into society" (trainer).

Among these values are solidarity and teamwork, highly valued by these staff members:

It's true that depending on the group you work with each year, you can achieve more or less, but anyway our intention is for sport to convey all the positive values you find in normal life and which are much more difficult to achieve here, like teamwork, supporting your teammates. Here people are quite a lot more selfish than you'd think... and with the sporting attitude in many cases we get them to share with other people (sports coordinator). 
That's basic (...) because thefeeling of solidarityand comradeship, well ... it's lacking here' (responsible from General Penitentiary Board). '...Saying you're sorry after a rough tackle, being concerned about an injured teammate or encouraging each other, you can hear that between them (trainer).

Another specifically identified value was responsibility: "It's a really positive tool when you're intervening socially, because it creates responsibilities" (trainer); and the sport was also said to teach inmates to resolve conflicts, to be more tolerant and to engage in dialogue: "The fact that, although there are little disputes between them, afterwards they can look for each other and talk, listen to each other and ... discuss things..." (trainer).

\section{Sport: Nothing more than entertainment and distraction for inmates?}

As the inmates confirmed to us, sport was indeed entertainment and distraction for them because it helped them to cope with internment and it broke the routine: "It's an outlet for distraction a bit for the brain and because you like it too, not to break with routine, because you still follow routine, you have to do that... And other stuff because sport is really good" (Francisco, inmate). "Time passes faster when you're doing something. Could be playing football with your friends..." (Manuel, inmate). "Football helps you get stuff off your chest, to play, to mix with people from other modules, to get some air... That's not to be sniffed at. Here that's a lot" (Antonio, inmate).

But in addition to this the inmates also affirmed that sport countered the prison subculture ("Talking about sport you've always got something to discuss and talk about," Juan, inmate), and increased social relationships among the internees and with the rest of society, teaching sociability: "Yes... this way you meet more people, new friends... it's good” (Manuel, inmate), "Doing sport helps you mix with people from the other modules" (Javier, inmate), "I think that sport always helps people to be more sociable and have more friends, right? To open yourself more to other people" (Juan, inmate). This was even true in relation to people from other cultures:

One really important factor that we should remember is that it encourages socializing among the inmates themselves and with the rest of society; we shouldn't forget the difficulties caused by living together in prison with a lot of inmates of other nationalities ... sport serves as a link between the inmate and society (prison director).
Also, the inmates stated that sport helped them to avoid taking drugs. "Yes... when I was outside, I smoked hash and so on, and here like you forget those things more, like you cope with it better without any kind of therapy or anything" (Teo, inmate).

The football school: A tool for imposing order and social control?

One of the main aims of the school is to teach the inmates to accept rules and discipline. This is clearly in evidence in two of the observation sheet transcripts:

One player throws the ball out at the end of the game. The coordinator reprimands the player. The trainer stays behind talking to the player. He also talks to the other players. It seems there is some kind of understanding between them; some hugs are exchanged. The inmate who threw the ball goes towards the door downcast and on his own. He seems to be strongly affected. The trainer comments to us after the session: "Just at the end of the match one of the inmates threw a ball at one of the modules... He said that it wasn't on purpose, his teammate said it wasn't on purpose, that he hadn't even thrown it at his own module... but well, the coordinator was quite clear about what he saw, that he chucked the ball really hard and well... in this activity it's regarded as serious." As a punishment the player was barred from doing the activity for a week. The sanction was not harsher because his teammates supported him and took responsibility for the error, and later he returned to the training sessions in a normal way, with no further problems in subsequent sessions. At the end one student throws his vest on the ground. The trainer orders him to pick up all the vest. At first, he refuses. In the end he goes to pick them up after the conversation with the trainer (observation sheet).

Learning to accept rules and regulations is an inseparable part of an individual's socialization process (Horton \& Hunt, 1987, p. 9). In Kant's words, liberty means the autonomy of the will, which only man, as a rational being, possesses; and mastering the will makes man free, since otherwise he would have to represent himself as subject only to the natural law of his needs: an animal only follows its desires and needs, while man, as a rational being, is only free when he is guided by his "good will" (Kant, 2007, pp. 51-52). This is why inmates need to recover (in some cases to develop for the first time) mastery of their will, in order to direct their own lives as rational beings. Learning to obey rules helps them in this process, which is why we consider this aspect to be crucial for them. 
Also, as a means of encouraging inmates to participate in the football programme (although the activity is well-received by them anyway) the prison employed a points system, also applied to other treatment activities seen as beneficial for rehabilitation and which complied with a certain set of characteristics.

They get points with the schools, in what's official, shall we say, and a bit more coordinated.. with organized sports activities they experience a certain discipline, for example with the Foundation's schools (...) Those who stay at it get points and well, they've got discipline and a task... The people in charge give us the information about attendance and performance and behaviour in these activities, and attitude; what I mean is that the points aren't only based on attendance, but also on attitude and performance (treatment subdirector).

Therefore, participation in the football school afforded the inmates benefits established by the prison itself. This factor has also been noted by other studies on sports in Spanish prisons (Martos, Devís \& Sparkes, 2009). Inmates received information on their points every three months, and they decided how to use them.

This will depend a lot on their situation in the prison. If they're people who are in custody awaiting trial, what they ask for most is communication with family or people close to them, having one family visit more every three months. If it's people who go out on temporary leave, as they can't ask for more visits because being out on leave cancels that, they ask for more sports or leisure equipment (sports coordinator).

This shows that the football programme was seen by the prison management as a treatment activity on the same level as the normal school providing prisoners with basic statutory education; and this in turn shows that the programme complied with another of the requisites for having a positive effect on inmates, i.e. the context was favourable, since it the support of the centre management and the other prison staff.

Further, this enables us to affirm that it was not used as an instrument of social control on the part of the prison. We would also support this with an additional argument, namely that only 30 prisoners took part (the maximum number of inmates that the service could cater for), out of around 800 prisoners in total. Thus, the question would be: what about the control and discipline of the vast majority of prisoners not participating in the programme?
Sport: Does it aid social reintegration?

According to Heinemann (1992), a person who is apt for living in society is one who has developed the characteristics of rule-compliance, identity, individual autonomy and solidarity. Following rules, however, must be balanced with the person's individuality; that is, the person must have an identity, which means knowing what her/his ideas and desires are, being able to recognize her/himself (the individual "I") separately from her/his surroundings (the collective "us"). We have already seen that the sports programme helped inmates accept rules and regulations and that it conveyed the value of solidarity to them. It also helped them to build a sense of identity and individual autonomy, i.e. to make them aware that they were subjects with responsibility for their own lives and in relation to those of others.

Er...yes. Because social reintegration, I see it as based on imbalance, based on... at some time in your life that maybe you think you're doing things well and that they're like that, and then because you go into prison... well maybe it changes the way you see things, you realise that no, things aren't like that, right? So sport, which helps you, of course it's going to help your social reintegration, because you do sport in a team, I mean you do sport with a lot of people, all types of sport, and you owe them, you owe them respect, you owe it to the rules, you owe it to them all. Yes, I think so (inmate, prison sports centre maintenance worker).

This factor is especially important in the case of exprisoners, when they are released and return to their social context. However, it is not enough; ex-inmates also have to be economically independent, to find a job which will allow them to keep themselves and to integrate socially. In this line, their participation in the football programme afforded some future professional opportunities, since they were offered courses to qualify as trainers, referees, etc; and this was seen as a substantial aid to their social reintegration:

I think that it's not only helpful but that it's essential... because there have been inmates who've left and through the federations, they've found a job, even if only temporary. But they referee matches in schools... what I mean is they earn money, that they also have the possibility of social integration, because for them it's basic (responsible from General Penitentiary Board).

The inmates themselves agree with this:

At the same time that we're doing something that's good for us we learn from the trainer, we learn 
a lot from him, and like me for one example, I did the sports monitor course, I got a diploma, a license, and I'm really glad about it. I think that when I get out, I won't be the right age to get into the world of football as a player but what I can do is run a team, help a trainer... whatever I can (Francisco, inmate).

On this issue all the interviewees called for support from the rest of society.

It's such a wide issue, social reintegration... that you have to treat it with kid gloves. I'm thinking about the development of each individual, and the development of the weaknesses which are behind his going to prison, and I think that depending on the crime at the moment when he recognizes it... The prisons have enough means with their staff and the support of the foundations and NGOs to improve inmates' behaviour. But when they leave here, they're totally... so-called, rehabilitated from the problems behind them going to prison, they go back to their own world; and in their world maybe they give up trying to reintegrate, because it's in their world that we should do the reintegration, in the rough areas with millions of problems. Here in the end we work with people who can be rehabilitated, but when they get out, what then? I can tell you that here we meet a lot of objectives, sport meets a lot of objectives, and people who've come in one way go out another. The problem is that then, once they're out, they have to look after themselves; and society... it's lacking, it's really lacking (sports coordinator).

\section{Conclusions}

Our findings show that a sports programme which brings together all the requisites for positive effects can contribute to the process of rehabilitation and reintegration for inmates, since in addition to transmitting values, it achieves their acceptance, learning and assimilation of rules and regulations as a habit of self-control; all of which are essential factors in living with others, as noted by Cagigal (1990). Also, such a programme can facilitate future professional opportunities and help avoid consumption of drugs.

With this we do not claim to refute those studies which have found negative effects for sports programmes, since in such studies the fulfilment of the requirements is not alluded to; hence we cannot know if they are fulfilled or not. This suggests two possibilities:

1) That they are not fulfilled, which would be consistent with their negative outcomes and with our findings, showing that there are prisons in which the practice of sports does not have the objective of contributing to inmates' social reintegration, and thus representing a clearly perverse use of sports in prison;

2) Alternatively, that they are fulfilled. This would refute the findings of our study and those which also register the benefits of sport in prison.

While when discussing prisoners' education and resocialization we should not forget that we are speaking of rational adults who can decide how they relate to the rest of society, it is also true that their determination not to re-offend, once outside, is key. Manzanos (1991) conceives social reintegration as:

A two-way endeavour: we should offer technical support and appropriate means to the person in conflict and/or difficulty, in order to tackle her/his problem and move on from her/his personal situation (...) The efforts of the individual we aim to help are an important part of the goals of reintegration; the other part belongs to the community (...) It is more difficult to achieve a positive attitude from the community than from the individual, and this is what lies behind many failures (p. 120).

Other authors (Woodall, Dixey \& South, 2013) also confirm the essential role that the rest of society plays in the reintegration of ex-prisoners, even affirming that inmates have better opportunities for training, education and healthcare in prison than in their home communities, which are plagued by a plethora of obstacles, including stigma, financial constraints and transport issues.

Thus, we conclude that a prison sports programme, correctly designed and carried out, may see its effects not achieved due to two factors:

- Because of the ex-prisoner, who may not have the firm resolve to change her/his way of life and avoid re-offending;

- And because of society, which does not take on responsibility for the reintegration of ex-prisoners by combatting prejudice and implementing programmes (including sports programmes) that promote social reintegration.

\section{Action proposals}

We affirm that sports programme in prison can make a fundamental contribution to internees' reintegration into society, but in order for this to occur, the following design and implementation guidelines should be adopted: the sports programme should:

1. Be adapted to the characteristics and needs of the target group; 
2. Have extension through time;

3. Have a monitor with enough training to enable her/him to promote values through the practice of sports, and in addition with a firm intention to achieve this;

4. Have a context (the prison management and staff) which is favourable to the sports programme being properly carried out.

5. Be led by people 'from outside' rather than professional prison staff;

6. Take place in the open air;

7. Involve team sports and offer a variety of sports activities which address the needs and interests of inmates;

8. Offer sports that can also be practiced when they leave prison;

9. Follow a schedule adapted to the physical and psychological characteristics of the inmates;

10. Include participation in competitions with teams from outside the prison;

11. Continue outside the prison, once the inmates have been released;

12. And operate with the consent and participation of the inmates themselves (Crabbe, 2000; Viñas, 2012).

We should not forget, however, that the reintegration of the ex-prisoner depends, in the last instance, on her/his own willingness and on the support of the rest of society.

We would like to finish with the following proposals:

- That sports programmes currently under way in Spanish should be revised, assessed and adjusted wherever necessary;
- That the General Penitentiary Board and the public and private institutions involved should continue to support the design and implementation of sports activities in Spanish prisons, providing them with proper and sufficient human and material resources;

- That research endeavours should focus on this topic and be supported, which will contribute to society's awareness of its responsibility for the social integration of people at risk of social exclusion in general, and for ex-prisoners in particular, offering specific ways of facilitating reintegration through a range of different tools and instruments, amongst which sports activities would play a prominent role;

- And lastly, that we should continue to study in depth the outcomes of sports activities in prison, specifically analysing the wide diversity of inmates that sports programmes are aimed at, such as: foreigners, drug addicts, women, prisoners with mental health problems, with different types of offences, etc. This should have the objective of boosting the benefits of sports for the social reintegration of each of these groups.

\section{Acknowledges}

The authors want to thank the Spanish General Penitentiary Board and the Real Madrid Foundation for their support to carry out this research.

\section{REFERENCES}

Aguilar, T., \& Asmussen, K. (1990). An exploration of recreational participation patterns in a correctional facility. Journal of Offender Counseling Services Rehabilitation, 14, 67-78. doi:10.1300/J264v14n01_07

Arribas, H.; Mantecón, L.; Rodríguez, R., \& Sánchez, I. (2001). Exclusión social y actividad física: propuestas de intervención educativa a través de contenidos sociomotrices, en dos contextos diferentes. In M. Latiesa; P. Martos, \& J.L. Paniza (eds.), Deporte y cambio social en el siglo XXI (pp. 367-382). Madrid: Esteban Sanz.

Bodin D.; Robène L.; Héas S., \& Sempé, G. (2007). Le sport en prison: entre insertion et paix sociale. Jeux, enjeux et relations de pouvoirs à travers les pratiques corporelles de la jeunesse masculine incarcérée. Revue d'histoire de l'enfance «irrégulière», 9, 145-171. doi:10.4000/ rhei.2213

Bredemeier, B. (1995a). Divergence in children's moral reasoning about issues in Daily life \& sport specific contexts. International Journal of Sport Psychology, 26, 453-463.

Bredemeier, B. (1995b). Moral reasoning and the perceived legitimacy of Intentionally injurious sport acts. Journal of Sport Psychology, 7, 110124. doi:10.1123/jsp.7.2.110

Buckaloo, B. J., Krug, K. S., \& Nelson, K. B. (2009). Exercise and the low-security inmate: Changes in depression, stress, and anxiety. The Prison Journal, 89(3), 328-343. doi:10.1177/0032885509339508
Cagigal, J.M. (1990). Deporte y agresión. Madrid: Alianza.

Callejo, J. (2002). Observación, entrevista y grupo de discusión: el silencio de tres prácticas de investigación. Revista Española de Salud Pública, 5(76), 409-422. doi:10.1590/S1135-57272002000500004

Cashin, A.; Potter, E., \& Butler, T. (2008). The relationship between exercise and hopelessness in prison. Journal of Psychiatric and Mental Health Nursing, 15, 66-71. doi:10.1111/j.1365-2850.2007.01207.x

Castillo, J. (2005). Deporte y reinserción penitenciaria. Estudios sobre Ciencias del Deporte, Serie Investigación, $n^{\circ} 39$. Madrid: Consejo Superior de Deportes, Ministerio de Educación y Ciencia.

Castillo, J. (2007). El deporte en la prisión española actual. In E. Gamero; J. Giménez; M. Díaz; P. Sáenz-López, \& J. Castillo (coord.), Violencia, Deporte y Reinserción Social, Vol. II. Estudios sobre Ciencias del Deporte, Serie Investigaciones, $n^{\circ} 48$ (pp. 179-194). Madrid: Superior de Deportes, Ministerio de Educación y Ciencia.

Chamarro, A. (1997). Determinantes psicosociales de la práctica de ejercicio físico en un centro penitenciario (Unpublished doctoral dissertation). Universidad de Salamanca, Salamanca.

Chamarro, A.; Blasco, T., \& Palenzuela, D.L. (1998). La práctica de ejercicio en las prisiones: factores asociados a la iniciación y el mantenimiento. Revista de Psicología del Deporte, 13, 69-91.

Chevry, P.; Aoun, M., \& Clement, M. (1992). Practiques sportives et con- 
duites addictives chez des hommes incarcérés, toxicomanes ou non. In Sport, Toxiques, Dependance: Congress International. Lyon: CNDT.

Clarke, A; Haag, K., \& Owen, N. (1986). Fitness Programs for Prison Inmates. The ACHPER National Journal, 112, 11-14.

Crabbe, T. (2000). A sporting chance? Using sport to tackle drug use and crime. Drugs: Education, Prevention and Policy, 7, 381-391. doi:10.1080/713660128

Crutchfield, E.; Garrette, L., \& Worrall, J. (1981). Recreation's place in prisons: A survey report. Parks and Recreation, 16(2), 35-39.

Cudd, B. (1978). Racquetball Behind the Walls. National Racquetball, 6, 34-36.

Devís, J., Martos, D. \& Sparkes, A. (2010). Socialización y proceso de construcción de la identidad profesional del educador físico de una prisión. Revista de Psicología del Deporte, 19 (1), 73-88.

Dewey, D. (1976). Convict Volunteers. Therapeutic Recreation Journal, 10, 99-102.

Domínguez, S., Jiménez, P.J. \& Durán, L.J. (2012). Práctica deportiva y estrategias de integración de la población ecuatoriana en Madrid. Cultura, Ciencia y Deporte (CCD), 7 (20), 81-88

Doty, J. (2006). Sports Build Character?! Journal of College and Character, 7(3). doi:10.2202/1940-1639.1529

Elger, B.S. (2009). Prison life: Television, sports, work, stress and insomnia in a remand prison. International Journal of Law and Psychiatry, 32(2), 74-83. doi:10.1016/j.ijlp.2009.01.001

Escartí, A.; Pascual, C., \& Gutiérrez, M. (2005). Responsabilidad personal y social a través de la educación física y el deporte. Barcelona: Graó.

Fornons, D. (2008). La práctica deportiva en la prisión: rehabilitación o evasión. In L. Cantarero; F.X., Medina, \& R. Sánchez (coords.), Actualidad en el deporte: investigación y aplicación. Actas XI Congreso de Antropología de la FAAEE. Donostia: Ankulegi Antropología Elkartea.

Gallant, D., Shery, E. \& Nicholson, M. (2014). Recreation or rehabilitation? Managing sport for development programs with prison populations. Sport Management Review 18(1), 45-56. doi:10.1016/j. smr.2014.07.005

Garnier, S.; Minotti, C., \& Labridy, S. (1996). Activités physiques et sportives et conduites de santé de femmes incarcérées. Science and Sport 11(3), 186-188. doi:10.1016/0765-1597(96)84033-0

González, P., \& Smith, H. (1974). On the Outside Looking Back. Parks and Recreation, 9, 21-23 \& 66-67.

Gras, L. (2005). Le sport in prison. Paris: Edition l'Harmattan.

Gutiérrez, M. (1995). Valores sociales y deporte. La Actividad Física y el Deporte como transmisores de valores sociales y personales. Madrid: Gymnos.

Hagan, J.H. (1990). Evaluating the effects of a high intensity fitness programme on inmates at Risdon Maximum Security Prison. In Actas de Commonweath and International Conference on Physical Education, (pp. 105-108). New Zealand: Auckland.

Harner, H. M., \& Budescu M. (2014). Sleep Quality and Risk for Sleep Apnea in Incarcerated Women. Nursing Research, 63(3), 158-169. doi:10.1097/NNR.0000000000000031

Heinemann, K. (1992). Socialización. En Diccionario Trilingüe de Ciencias del Deporte. Málaga: Unisport, Junta de Andalucía.

Horton, P.B., \& Hunt, C.L. (1987). Sociología. Madrid: MacGraw-Hill.

Ionescu, S.; Parisot, D., \& Irode, A. (2010). Le Sport en Milieu Carceral: la Perception des Detenus sur la Pratique Sportive. Sport Science Review, 19(1-2), 149-158. doi:10.2478/v10237-011-0009-8

Kant, I. (2007). Fundamentación de la Metafísica de las Costumbres. San
Juan, Puerto Rico: Pedro M. Rosario Barbosa. Retrieved from http:// pmrb.net/books/kantfund/fund_metaf_costumbres_vD.pdf

Leberman, S. (2007). Voices behind the walls: Female offenders and experiential learning. Journal of Adventure Education \& Outdoor Learning, 7, 113-120. doi:10.1080/14729670701485832

Lechich, M.L. (1984). Health Education in a Women's Prison. Health Education, 6, 34-36. doi:10.1080/00970050.1984.10615773

Lobo, J.A.F. (1975). A study of Scope, Content and Function of Recreation in a Maximum Security Prison. Tesis Doctoral. Australia: University of Western Australia.

Long, R. (1983). The Prison Running Connection. En B. Anderson, (Dir.), The Complete Runner, vol 2, chapter 5. California: World Publications.

Manzanos, C. (1991). Cárcel y marginación social: contribución crítica e investigación aplicada a la sociedad vasca. Donostia: Hirugarren Prentsa.

Martos-García, D.; Devís-Devís, J., \& Sparkes, A.C. (2009). Deporte entre rejas. ¿Algo más que control social? RIS Revista Internacional de Sociología, 67(2), 391-412. doi:10.3989/RIS.2007.07.26

Middleton, C. (1983). Inside Story. We go behind bars to find how sport is run in Winchester prison. Sport and Leisure, 24, 14-16.

Moscoso, D.; Pérez, A.; Muñoz, V.; González, M., \& Rodríguez-Morcillo, L. (2012). El deporte de la libertad. Deporte y reinserción social de la población penitenciaria en Andalucía. Anduli. Revista Andaluza de Ciencias Sociales, 11, 55-70.

Negro, C. (1995). Actividades en los centros penitenciarios. In P. Rodríguez, \& J.A. Moreno (dirs.), Perspectivas de actuación en Educación Física (pp. 229-245). Murcia: Universidad de Murcia.

Nelson, M., Specian, V. L., Tracy, N. C., \& DeMello, J. J. (2006). The effects of moderate physical activity on offenders in a rehabilitative program. Journal of Correctional Education, 57(4), 276-285.

O’Morrow, G.S., \& Reynolds, R.P. (1989). Therapeutic Recreation: A Helping Profession. Englewood Cliffs, Prentice-Hall Inc.

Pérez-Moreno, F; Cámara-Sánchez, M.; Tremblay, J.; Rivera-Rubio, V; Gil-Paisán, L., \& Lucía, A. (2007). Benefits of exercise training in Spanish prison inmates. International Journal of Sports Medicine, 28, 1046-1052. doi:10.1055/s-2007-965129

Reeves, R.A. (1973). Personality Differences Between Athletic and Nonathletic Inmates at the State Prison in Utah (Unpublished doctoral dissertation). University of Utah, Utah.

Ríos, M. (1986). L'activitat físico-esportiva en una presó de dones. Apunts, 4, 52-59.

Ríos, M. (2004). La educación física en los centros penitenciarios de Cataluña. Tándem, 15, 69-82.

Sabo, D. (2001), Doing time, doing masculinity en Sports and prison. Sabo, D., Kupers y W. London, Prison Masculinities, Philadelphia, Temple University Press, pp. 61-66.

Stöver, H., \& Thane, K. (2011). Towards a continuum of care in the EU criminal justice system. A survey of prisoners' needs in four countries (Estonia, Hungary, Lithuania, Poland). Oldenburg/Germany: Bis-Verlag.

Viñas, E.I. (2012). Pena, tratamiento y deportes (particularmente en el Rugby). Itinere. Revista Digital de Estudios Humanísticos de la Universidad de FASTA, 2(2), 57-81.

Wandzilak, T. (1985). Values development through physical education and athletics. Quest, 37(2), 176-185. doi:10.1080/00336297.1985.1 0483832

Woodall, J.; Dixey, R., \& South, J. (2013). Control and choice in English prisons: developing health-promoting prisons. Health Promotion International, 29(3), 474-482. doi:10.1093/heapro/dat019 


\section{Dobles titulaciones que mejoran las salidas profesionales}

L.o.

- La práctica deportiva no para de crecer en el mundo entero. Los beneficios de practicarun deporte están cada vez más extendidos y son incuestionables.

El Grado en Ciencias de la Actividad Física y del Deporte de la Universidad Católica de Murcia se adapta a esta nueva y creciente demanda de actividad física y a los cambios que ello supone, po lo que en el próximo curso académico los alumnos podrán realizar de forma simultánea al Grado en CAFD ocho títulos propios que les permitirán especia-

lizarse en las ramas del deporte que más les interesan y ampliarán sus salidas profesionales. También podrán cursar estos tí tulos los egresados y profesionales del sector que quieran obtener una mayor preparación en una determinada área.

La Facultad del Deporte de la UCAM cuenta con gran prestigio nacional e internacional que ha conseguido tras años de trabajo ofreciendo la mejor formación a sus estudiantes. Las altas cifras de matriculación muestran su consolidación como una de las mejores universidades españolas

\section{¿QUIÉN PUEDE CURSAR LOS TÍTULOS DE GRADUADO SUPERIOR UNIVERSITARIO? \\ - Los estudiantes, durante la carrera \\ - Egresados universitarios \\ - Profesionales con experiencia acreditada}

para estudiar este Grado, que a (Terapeuta Físico), Fitness y Departir del próximo curso ofertará, sarrollo Muscular, Gestión y Diademás, los títulos propios de rección de Entidades Deportivas GraduadoSuperior Universitario (Sport Management), Marketing en Actividad Física Terapéutica Deportivo, Alto Rendimiento Deportivo(NSCA), Nutrición portivo(NSCA), Nutrición

\section{MENCIONES OFICIALES}

Entrenamiento deportivo (Entrenador deportivo)

- Gestión y Recreación Deportiva (Gestor deportivo)

Educación Física y Deportiva (Educador deportivo)

- Reeducación Física y Deportiva (Reeducador físico y deportivo)

- Vela Deportiva y Organización de Regatas (Especialista en Vela deportiva y organización de regatas)
EN:
Socorrismo D ar todos los prin que sustentan la actividad física y del deporte y aplicarlos a la anatomía, la fisiología, la psicología, la sociología pedagogía, etcétera. El estudiante tiene la oportunidad de esta en contacto directo con la realidad del trabajo realizando prácticas reales y con la opción de involucrarse en lagestión, promoción o investigación en Ciencias del Deporte.

El Grado en CAFD y los títulos propios de Graduado Superior Universitario tienen muchas aplicaciones a la vida social y laboral El egresado en CAFD puede ejercerla enseñanza ypedagogía, formando a estudiantes en escuelas e institutos, profundizar en el entrenamiento deportivo o en programas de actividad física y de salud o dirigir instalaciones deportivas. Y es que el deporte además de ser un modo de vida es también una oportunidad de desa rrollo empresarial que permite emprender poniendo en marcha iniciativas ynegocios en el ámbito deportivo.

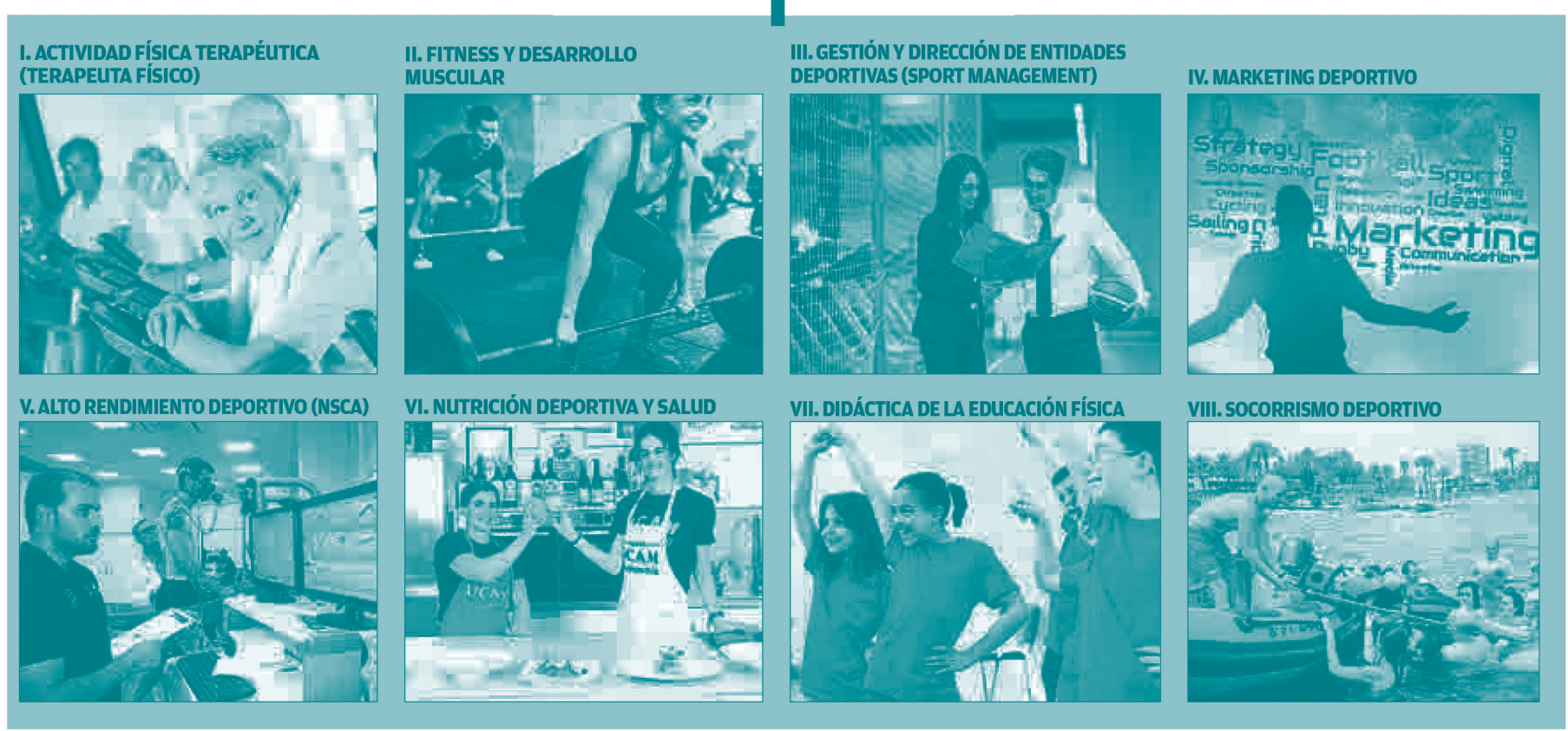

- El Grado en CAFD se puede estudiar en el Campus de Murcia y en el Campus de Cartagena. Se imparte en inglés y en español y las prácticas laborales se pueden realizar en los diferentes clubes deportivos de la UCAM, entre otros.

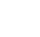

